\title{
The Effect of Land Unit Elimination on The Conservation Activity Plan at Air Bengkulu Watershed, Bengkulu Province
}

\author{
Bambang Sulistyo $^{1^{*}}$, Muhammad Faiz Barchia ${ }^{1}$, Kanang Setyo Hindarto ${ }^{1}$, Noviyanti Listyaningrum ${ }^{2}$ \\ ${ }^{1}$ Faculty of Agriculture, University of Bengkulu, Kandang Limun, Bengkulu, Indonesia \\ ${ }^{2}$ Graduate School, University of Gadjah Mada, Bulaksumur, Yogyakarta, Indonesia
}

Received: 2019-08-08

Accepted: 2020-06-29

Keywords:

Change;

Conservation;

land unit elimination

Correspondent email:

bsulistyo@unib.ac.id

\begin{abstract}
To enable conservation of degraded land requires Map of Conservation Activity Plan (CAP). The map is established based on a model developed by the then Ministry of Environment and Forestry. One step to analyze the CAP is land unit elimination (LUE) having area of $<1 \mathrm{~cm}^{2}$. This study aimed to determine the effect of LUE on the CAP at Air Bengkulu Watershed. Maps used for input to CAP are EHL (Erosion Hazard Level), Soil Depth, Slope, Population Pressure, and the Recommended Landuse, whereas to calculate EHL requires $\mathrm{R}, \mathrm{K}, \mathrm{LS}, \mathrm{C}$, and P Factors. CAP Map as a result without involving LUE is compared to the CAP Map with involving LUE. The research result showed that the LUE influences on the change of the recommended of the CAP up to $77.6 \%$ of the total area of the study, either in engineering recommended or in vegetatively recommended conservation, while the rest $(22.4 \%)$ were unchanged.
\end{abstract}

\section{Introduction}

Production of food, fuel, fiber, and many other essential goods requires land resource to meet human and animal needs. Unfortunately, land is facing serious threats of deterioration due to unrelenting human pressure and utilization incompatible with its capacity (Alkharabsheh, Alexandridis, Bilas, Misopolinos, \& Silleos, 2013; Tagore, Bairagi, Sharma ${ }^{a}$, Sharma ${ }^{b}$, Bhelawe, \& Verma, 2013; Bohre \& Chaubey, 2014). Land degradation is the process that makes land unsuitable for human beings as well as for soil ecosystems as a result of anthropogenic activities and climatic variations (Barbero-Sierra, Marques, Ruiz-Pérez, Escadafal, \& Exbrayat, 2015). The amount of degraded land is accelerating from year to year due to the uncontrollable pressure of population and economic growth (Fulazzaky \& Gany, 2009), while the rate of conserving them cannot overcome the rate of damage.

Ministry of Forestry, in 2002, has issued data that Indonesia had degraded forest area of 96.3 million hectares, 54.6 million hectares including production forest areas, conservation forests and protected forests, while 41.7 million hectares outside forest areas (Nawir, Murniati \& Rumboko, 2008). The data certainly has changed and tends to increase.

The Air Bengkulu Watershed is the most critical watershed in Bengkulu Province. Almost 90\% of the area is located in Central Bengkulu Regency spreading in 4 subdistricts (Taba Penanjung, Karang Tinggi, Pondok Kelapa, and Talang Empat), with 36.134 inhabitans leading to the population density of $78 / \mathrm{KM}^{2}$ (BPS Kabupaten Bengkulu Tengah, 2018). Only $10 \%$ of the watershed is located in Bengkulu City spreading in 3 sub-districts (Gading Cempaka, Muara Bangkahulu, and Teluk Segara), with 91.957 inhabitans leading to the population density of 1.755 / $\mathrm{KM}^{2}$ (BPS Kota Bengkulu, 2018).
The most essential strategic issue in the Air Bengkulu Watershed is the water crisis. This issue was raised because the people around the Bengkulu River complained about poor water quality and relatively small quantities. This poor water quality is due to sedimentation from erosion of coal mining areas in the upstream area. River flow patterns that carry eroded material from the catchment flows to the Air Bengkulu Watershed. This flow results in run-off flow in the former minelayer so that the water quality decreases. The indicator of pollution is caused by a significant high value of TSS (Total Suspended Solid) levels exceeding the quality standard $(50 \mathrm{~mm} / \mathrm{l})$ that is $219.20 \mathrm{~mm} / \mathrm{l}$ during the dry season and $175.75 \mathrm{~mm} / \mathrm{l}$ in the rainy season (Supriyono, Iskarni, \& Barlian, 2015).

The erosion that occurred in the Air Bengkulu Watershed is caused by several factors such as the loss of vegetation cover arising from deforestation, agricultural practices, residential areas, grasslands and the most dominant indication is coal mining. The condition of relatively steep slopes with narrow peaks spread around the watershed has the potential to cause erosion. The intensity of the average rainfall is also quite large between $2800-3100 \mathrm{~mm} /$ year, besides it is followed by coal mining activities, can potentially increase runoff and high erosion around the watershed.

Efforts to improve the condition of degraded land will be carried out well if objective conditions information can be thoroughly identified (Tarigan, 2012; Gibbs \& Salmon, 2015). Provision of data and information is needed, especially in supporting efficient strategy formulas, so that it is expected to obtain a reference in allocating resources proportionally. This means that to overcome the problem of degraded land a Map of Conservation Activity Plan 
(hereinafter abbreviated as CAP) is needed so that the priority areas must be addressed, what actions must be taken, and how much funds are required.

However, the preparation of the CAP Map depicting the actual conditions will take a long time, much resources and funds if the survey is carried out manually or terrestrially. To overcome this problem, a model was created to map the distribution without having to do a direct survey. In 1998, the Ministry of Forestry (now, the Ministry of Environment and Forestry) has developed a mapping model to deal with degraded land and has been implemented in Indonesia (Ministry of Forestry, 2009). This model has been adopted by various Government Institutions, NGOs and universities (Prasetya \& Gunawan, 2012).

The CAP is formulated as (Ministry of Forestry, 2009): CAP $=$ Slope + EHL + Soil Depth + Population Pressure + Recommended Landuse

EHL (Erosion Hazard Level) is produced by overlaying the results of erosion with a soil depth map. The amount of erosion is calculated using the USLE (Universal Soil Loss Equation) formula (Wischmeier \& Smith, 1978):

$\mathrm{A}=\mathrm{R} \times \mathrm{K} \times \mathrm{LS} \times \mathrm{C} \times \mathrm{P}$

where:

$\mathrm{A}=$ mean annual soil erosion rate in (ton/hectare/year)

$\mathrm{R}$ = rainfall erosivity factor ( $\mathrm{R}$ factor) in $(\mathrm{MJ} \mathrm{mm} / \mathrm{ha} / \mathrm{h} /$ year)

$\mathrm{K}=$ soil erodibility factor ( $\mathrm{K}$ factor) in (ton hectare/MJ/ $\mathrm{mm}$ )

LS = slope length and steepness factor (LS factor) (dimensionless)

$\mathrm{C}$ = cover and management factor ( $\mathrm{C}$ factor) (dimensionless)

$\mathrm{P} \quad=$ support practice factor (P factor) (dimensionless)

All those input parameters are collected and the data is then analyzed to finally the results are presented as CAP Map. Before the erosion calculation is carried out, a land unit map is made which is the result of an overlay analysis among maps of soil type, slope and land use to produce new land units. If there is a land unit whose area is $<1 \mathrm{~cm}^{2}$ on a map, then elimination must be done (Ministry of Forestry, 2009). For watershed conservation, a scale map of 1: 50.000 is used. When the scale of the map compiled is a scale of $1: 50,000$, so that units of land with an area of $<25$ hectares will be eliminated, that is, combined with a unit of land nearby in such a way that the size of the land unit is $25 \geq$ hectares. The illustration of the process of land unit elimination is presented in Figure 1.

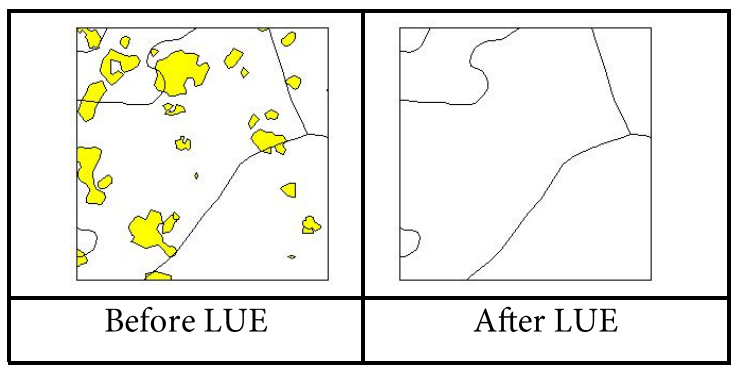

Figure 1. The illustration of the process of land unit elimination
The study aimed to determine the effect of land unit elimination on the CAP, specifically in the Air Bengkulu Watershed, Bengkulu Province.

\section{The Methods}

The research site is the Air Bengkulu Watershed which is administratively included at the border of Bengkulu City and Bengkulu Tengah Regency, Bengkulu Province. Geographically located between East Longitude $102^{\circ} 14^{\prime} 48.962^{\prime \prime}$ to $102^{\circ} 35^{\prime} 5.992^{\prime \prime}$ and South Latitude $3^{\circ} 37^{\prime} 8.705^{\prime \prime}$ up to $3^{\circ} 50.302^{\prime \prime}$, while the area covers $50,049.8$ hectares.

The main data required in this study include: Topographic Map of 1: 50,000 scale; The Land Unit and Soil Map of 1: 250,000 scale; Map of Bengkulu Province Watershed of 1: 50,000 scale; Map of Bengkulu Province Forest Status of 1: 50,000 scale; Landsat 8 OLI Satellite Imagery covering the Air Bengkulu Watershed; and Rainfall Data from BMKG Station of Pulau Baai, Bengkulu. The different map scales that will be used in the research will not affect the overlay analysis, but will affect the decision in choosing the number of soil samples to be taken.

Software and tools for research purposes include: ILWIS Program (Integrated Land and Water Information System) version 3.4 and its hardware to process raster-based data; ArcView Version 3.3 and/or ArcGIS version 10.1 and their devices for vector-based data analysis and creation of map layouts; Binoculars, compass, tent, rings, drill, meter and Global Positioning System (GPS) for field equipment; and other types of equipment that help facilitate activities.

The research flow diagram for the calculation of erosion and CAP, with or without the elimination of land units, is presented in Figure 2. The stages of the research include: 1) the preparation, 2) digital classification of Landsat 8 OLI image, 3) the data and map analysis; 4) fieldwork, 5) reclassification and overlay analysis, and 6) map preparation and paper writing.

Equation (1) and (2), implicitely, mentioned that the preparation of CAP requires the input of EHL, Soil Depth, Slope, Population Pressure, and the Recommended Landuse whereas to calculate EHL it requires R Factor, K Factor, LS Factor, C Factor, and P Factor. In the map analysis stage, the formulae and criteria used are as follows:

To get R Factor, rainfall data during 10 years were collected from BMKG (Agency for Meteorology, Climatology and Geophysics). Then, the R Factor is calculated using the Bols formula (1978) as:

$\mathrm{R}_{\mathrm{m}}=6.119 \times(\text { Rain })_{\mathrm{m}}^{1.21} \times(\text { Days })_{\mathrm{m}}{ }^{-0.47} \mathrm{x}(\text { Max P })_{\mathrm{m}}{ }^{0.53}$

where :

$\mathrm{R}_{\mathrm{m}} \quad=$ Average rain erosivity index (unit/month)

$(\text { Rain })_{\mathrm{m}}=$ Monthly average of rain $(\mathrm{cm} / \mathrm{month})$

$(\operatorname{Max} \mathrm{P})_{\mathrm{m}}=$ Daily maximum average of rainfall $(\mathrm{cm})$

$(\text { Days })_{\mathrm{m}}=$ Monthly average of the number of rainy days

To get K Factor, 50 soil samples were collected from field at different location and different land unit. During the collection, the soil structure was observed directly, while the soil texture, permeability, and soil organic matter were analyzed at the laboratory. Then, the determination of the $\mathrm{K}$ value can be done using the following formula (Wischmeier \& Smith, 1978): 


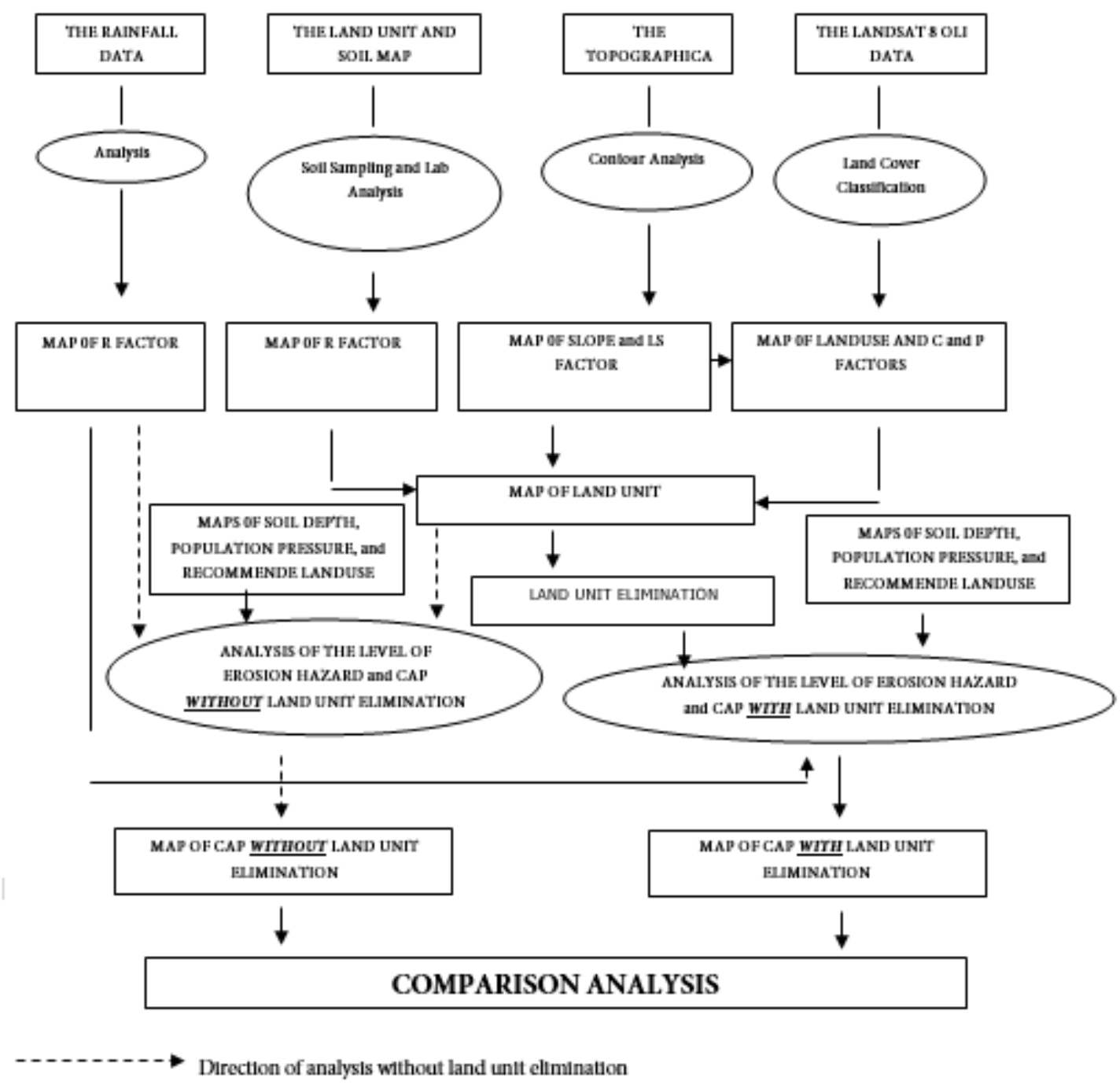

Figure 2. Flow diagram of the study

$\mathrm{K}=\left\{2.17 \times 10^{-4} \times(12-\mathrm{OM}) \times \mathrm{M}^{1.14}+4.20 \times(\mathrm{s}-2)+3.23 \times(\mathrm{p}-\right.$ 3) $\} / 100$

in this case, $\mathrm{K}$ is soil erodibility, $\mathrm{OM}$ is the percentage of organic matter, $s$ is the class of soil structure, $p$ is the class of soil permeability and $\mathrm{M}$ is $\{(\%$ clay $+\%$ very fine sand $) \mathrm{x}$ (100 - \% clay)\}.

The LS Factor is calculated using the following formula: For slopes $\leq 20 \%$ the formula is (Schwab, Fangmeier, Elliot et al., 1993):

$L S=\sqrt{ }\left\{\left(L_{a}\right) \times\left(1,38+0,965 s+0,138 s^{2}\right) / 100\right\}$

For slopes $>20 \%$ formulas are used (Goldman, Jackson \& Bursztynsky, 1986):

$\mathrm{LS}=\left[\left(65,41 \times \mathrm{x} \mathrm{s}^{2}\right) /\left(\mathrm{s}^{2}+10.000\right)+(4,56 \times \mathrm{s}) /\left(\mathrm{s}^{2}+10.000\right)^{0,5}+\right.$ $0,065]\left[\left(\mathrm{L}_{\mathrm{a}} / 22,13\right)^{\mathrm{m}}\right]$

in the formula, $\mathrm{L}_{\mathrm{a}}$ is the slope length (in meters), $\mathrm{s}$ is the angle of the slope (in \%), $\mathrm{m}$ is the constant number, the magnitude depends on the slope, ie $\mathrm{m}=0.1$ if $\mathrm{S} \leq 1 \%$; $\mathrm{m}=$ 0.3 if $\mathrm{S}>1 \%$ and $\mathrm{S} \leq 3 \% ; \mathrm{m}=0.4$ if $\mathrm{S}>3 \%$ and $\mathrm{S}<5 \%$; and $\mathrm{m}=0.5$ if $\mathrm{S} \geq 5 \%$.

Prior to the determination of the $\mathrm{C}$ Factor, land cover classification derived from Landsat 8 Oli Data was done.
After some ground check to verify the correctness of the classification, then the $\mathrm{C}$ Factor value is taken from the Regulation of the Minister of Forestry of the Republic of Indonesia Number: P. 32/Menhut-II/2009 concerning Procedures for the Preparation of a Conservation Technical Plan (Ministry of Forestry, 2009).

The $\mathrm{P}$ factor is determined according to the study of Abdurachman, Barus, \& Kurnia (1985) that is by combining slope data with land use.

Population Pressure Map can be obtained by interpreting and delineating residential areas from satellite images. Population Pressure is categorized as High in residential areas, whereas outside residential areas are categorized as Low Population Pressure.

Map of Soil Depth can be derived from The Land Unit and Soil Map.

Map of Recommended Land Use is derived from the Forest Status Map combined with the protected areas of the waterbody (Coastal area and Riverside) and the distribution of cultivation areas for Seasonal Crops (if the slope is $<15 \%$ ) and for Annual Plants (if the slope is $\geq 15 \%$ ). After the estimated annual average erosion (A) is calculated using the formula (2), then the result is overlaid on soil depth data to determine EHL for each land unit. EHL class is estimated in each land unit using simple matrix criteria as shown in Table 1. 
EHL map is overlaid on maps of Population Pressure, Soil Depth, Slope, and Recommended Land Use to obtain the Recommended CAP as formulated in Equation (1) and according to the criteria as presented in Table 2, while the detailed explanation for each symbol is presented in Table 3 and Table 4.

Table 1. The Level of Erosion Hazard

\begin{tabular}{|c|c|c|c|c|c|}
\hline \multirow{4}{*}{ Soil Depth $(\mathrm{cm})$} & \multicolumn{5}{|c|}{ The Level of Erosion Hazard } \\
\hline & I & II & III & IV & $\mathrm{V}$ \\
\hline & \multicolumn{5}{|c|}{ Erosion (ton/hectare/year) } \\
\hline & $<15$ & $15-60$ & $60-180$ & $180-480$ & $>480$ \\
\hline Deep & SR & $\mathrm{R}$ & $\mathrm{S}$ & $\mathrm{B}$ & SB \\
\hline$>90$ & 0 & I & II & III & IV \\
\hline Moderately & $\mathrm{R}$ & $\mathrm{S}$ & $\mathrm{B}$ & SB & SB \\
\hline $60-90$ & I & II & III & IV & IV \\
\hline Shallow & $\mathrm{S}$ & $\mathrm{B}$ & SB & SB & SB \\
\hline $30-60$ & II & III & IV & IV & IV \\
\hline Very Shallow & $\mathrm{B}$ & SB & SB & SB & SB \\
\hline$<30$ & III & IV & IV & IV & IV \\
\hline
\end{tabular}

Remarks:

(Source: Ministry of Forestry, 2009)

0 - SR = Very Slightly; I - R = Slightly; II - S = Moderately; III - B = Heavily; IV - SB = Very Heavily

Table 2. Recommended Conservation Activity Plan

\begin{tabular}{|c|c|c|c|c|c|c|c|c|}
\hline \multirow{3}{*}{ Slope } & \multirow{3}{*}{$\begin{array}{l}\text { Soil } \\
\text { Depth }\end{array}$} & \multirow{3}{*}{ EHL } & \multicolumn{6}{|c|}{ Recommended CAP } \\
\hline & & & \multicolumn{3}{|c|}{ High Population Pressure } & \multicolumn{3}{|c|}{ Low Population Pressure } \\
\hline & & & FL & FBT & FBS & $\mathrm{FL}$ & FBT & FBS \\
\hline \multirow[t]{2}{*}{$0-15$} & M, D & $\mathrm{S}, \mathrm{B}, \mathrm{SB}$ & $\mathrm{T}(1,2,6,7,8)$ & $\mathrm{T}(1,2,3,6,7,8,9)$ & $\mathrm{T}(1,2,6,7,8,9)$ & $\mathrm{T}(1,2,4,6,7,8)$ & $\mathrm{T}(1,2,3,6,7,8,9)$ & $\mathrm{T}(1,2,3,6,7,8,9)$ \\
\hline & & & $\mathrm{V}(1,2,4,9,10,14)$ & $\mathrm{V}(2,3,4,5,6,7,12)$ & $\mathrm{V}(2,3,4,5,6,7)$ & $\mathrm{V}(4,11,14)$ & $\mathrm{V}(2,3,4,5,6,7,9,10,12)$ & $\mathrm{V}(2,3,4,5,6,7)$ \\
\hline \multirow[t]{2}{*}{$15-25$} & $\mathrm{M}, \mathrm{D}$ & $\mathrm{S}, \mathrm{B}, \mathrm{SB}$ & $\mathrm{T}(1,2,4,6,7)$ & $\mathrm{T}(1,2,3,4,6,7,8,9)$ & $\mathrm{T}(1,2,3,6,7,8,9)$ & $\mathrm{T}(1,2,4,6,7,8)$ & $\mathrm{T}(1,2,3,4,6,7,8,9)$ & $\mathrm{T}(1,2,3,5,6,7,8,9)$ \\
\hline & & & $\mathrm{V}(4,9,10,11,12,14)$ & $\mathrm{V}(2,3,4,5,6,7,12)$ & $\mathrm{V}(2,3,4,5,6,7)$ & $\mathrm{V}(4,9,10,11,12)$ & $\mathrm{V}(2,3,4,5,6,7,9,10,12)$ & $\mathrm{V}(2,3,4,5,6,7)$ \\
\hline \multirow[t]{2}{*}{$25-40$} & $\mathrm{M}, \mathrm{D}$ & $\mathrm{S}, \mathrm{B}, \mathrm{SB}$ & $\mathrm{T}(1,2,4,6,7,8)$ & $\mathrm{T}(1,2,3,4,6,7,8,9)$ & $\mathrm{T}(1,3,6,7,8,9)$ & $\mathrm{T}(1,2,4,6,7,8)$ & $\mathrm{T}(1,2,3,4,6,7,8,9)$ & $\mathrm{T}(1,3,6,7,8,9)$ \\
\hline & & & $\mathrm{V}(4,9,10,11,12,14,16)$ & $\mathrm{V}(2,3,4,6,7,12)$ & $\mathrm{V}(2,3,4,6,7)$ & $\mathrm{V}(4,9,10,12)$ & $\mathrm{V}(2,3,4,5,6,7,9,10,12)$ & $\mathrm{V}(2,3,4,6,7)$ \\
\hline \multirow[t]{2}{*}{$>40$} & M, D & $S, B, S B$ & $\mathrm{~T}(1,4,6)$ & $\mathrm{T}(1,4,6,9)$ & $\mathrm{T}(1,4,6,9)$ & $\mathrm{T}(1,6)$ & $\mathrm{T}(1,4,6,9)$ & $\mathrm{T}(1,4,6,9)$ \\
\hline & & & $\mathrm{V}(9,10,11,12,14,16)$ & $\mathrm{V}(2,3,6,7,12)$ & $\mathrm{V}(2,3,6,7)$ & $\mathrm{V}(9,10,11,14)$ & $\mathrm{V}(2,3,6,7,12)$ & $\mathrm{V}(2,3,6,7,12)$ \\
\hline \multirow[t]{2}{*}{$>15$} & Whole & Set & $\mathrm{T}(14)$ & $\mathrm{T}(14)$ & $\mathrm{T}(14)$ & $\mathrm{T}(14)$ & $\mathrm{T}(14)$ & $\mathrm{T}(14)$ \\
\hline & & & $\mathrm{V}(5)$ & $\mathrm{V}(5)$ & $\mathrm{V}(5)$ & $\mathrm{V}(5)$ & $\mathrm{V}(5)$ & $\mathrm{V}(5)$ \\
\hline
\end{tabular}

Remarks:

Recommended Land Use

FL : Protected Area

FBS : Seasonal Crops

FBT : Annual Plants
Soil Depth

$\mathrm{S} \quad: 15-30 \mathrm{~cm}$

M :30-60 cm

$\mathrm{D} \quad:>60 \mathrm{~cm}$
The EHL

S : Moderately Eroded

B : Heavily Eroded

SB : Very Heavily Eroded 
Table 3. Recommended of Vegetatively Conservation Activity Plan

\begin{tabular}{ll}
\hline Symbol & Soil conservation measures \\
\hline V1 & Pasture or grassland \\
V2 & Multiple cropping including crop rotation, relay cropping, mixed cropping and intercropping \\
V3 & contour cropping, strip cropping, alley cropping \\
V4 & Reduced tillage including minimum tillage and no-till (zero tillage) \\
V5 & Grass strip/barrier \\
V6 & Cover cropping \\
V7 & Organic matter management including use of mulch, and incorporation of compost, animal manure, green ma- \\
V8 & nure and crop residues \\
V9 & Hedgerow, live fence \\
V10 & Protection forest including recreational forest and Forest Park and Forest Reserves \\
V11 & Permanent vegetation crops including industrial and estate crops, orchards \\
V12 & Agroforestry including mixed gardens and home gardens \\
V13 & Replanting of clear-felled forest \\
V14 & Regeneration of clear-felled forest \\
V15 & Protection of rivers and springs \\
V16 & Silvopasture \\
V17 & Planting of trees, shrubs and grasses primarily for soil conservation purposes \\
\hline
\end{tabular}

Table 4. Recommended of Engineering Conservation Activity Plan

\begin{tabular}{ll}
\hline Symbol & Soil conservation measures \\
\hline T1 & Ridge terrace including graded contour bund \\
T2 & Credit terrace \\
T3 & Bench terrace including level bench terrace, reserve sloping, bench terrace, forward sloping, bench terrace, gar- \\
T4 & Inderrace, stone wall terrace, interrupted bench terrace \\
T5 & Hillside ditch or interception ditch \\
T6 & Waterway \\
T7 & Trash line \\
T8 & Silt pit witch or without slot mulch \\
T9 & Drop structure usually of stone or bamboo supported by grasses ( as part of water disposal in a terrace system) \\
T10 & Sediment control including check dams and detention dams \\
T11 & Gully control including gully head structures (flumes and chutes), check dams \\
T12 & Flood, control and/or river bank protection \\
T13 & Road protection \\
T14 & Control of erosion and runoff from settlement areas including use of soak pits, absorption well, drop structures \\
\hline
\end{tabular}

\section{Result and Discussion}

Eight maps of the Air Bengkulu Watershed as a result of analysis and will be used as input for analysis of the CAP are presented in Figure 3.

Figure 3 (a) shows that the pattern of increasing erosivity values is in line with the increase in Air Bengkulu Watershed elevation, the higher the elevation, the higher the erosivity value. The most extensive value of erosivity occurs at 3,550 (MJ/ha) (mm/hour), while the narrowest is at 2,350 (MJ/ha) (mm/hour). 


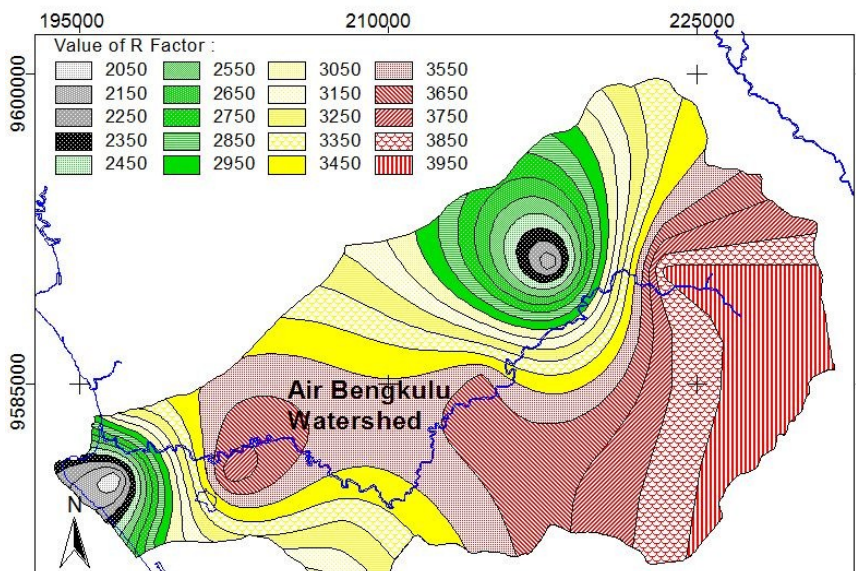

3000 6oge 900012000 Meters

(a) Map of The R Factor
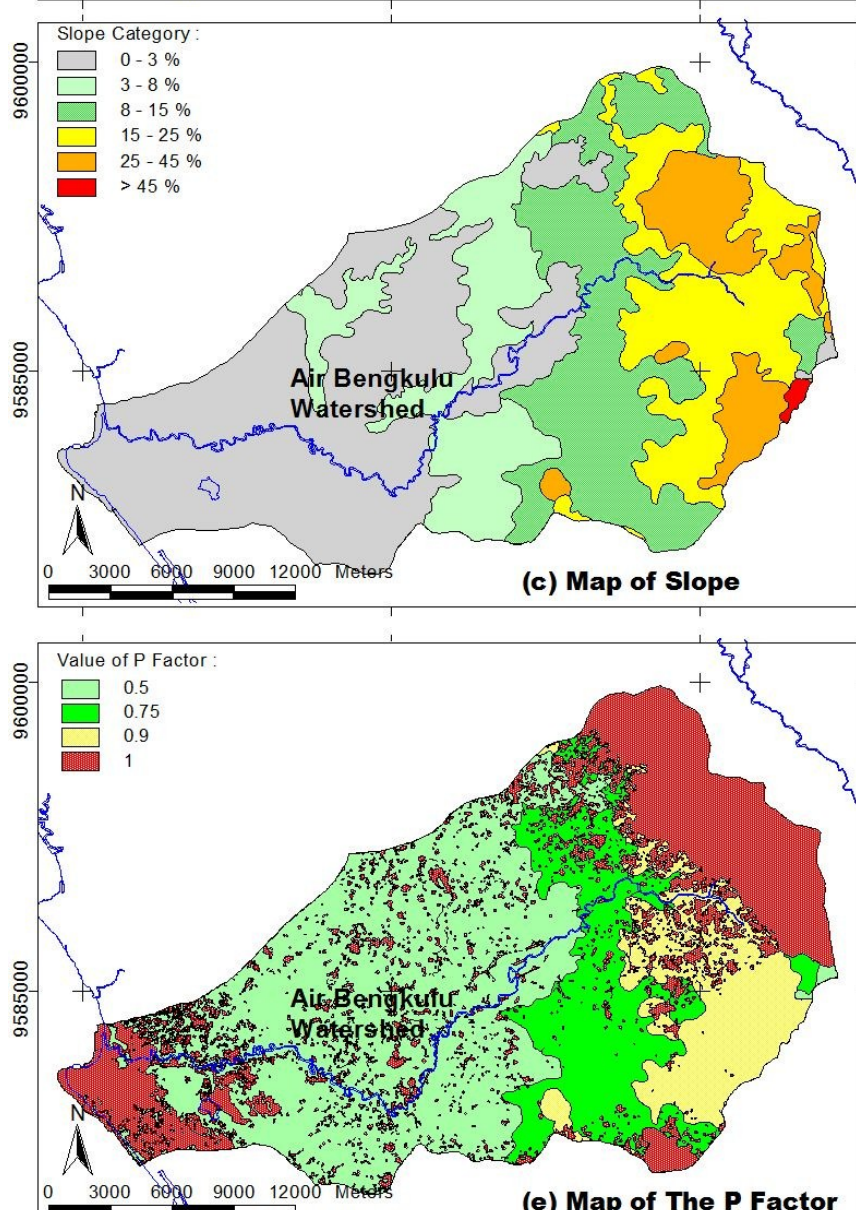

(e) Map of The P Factor

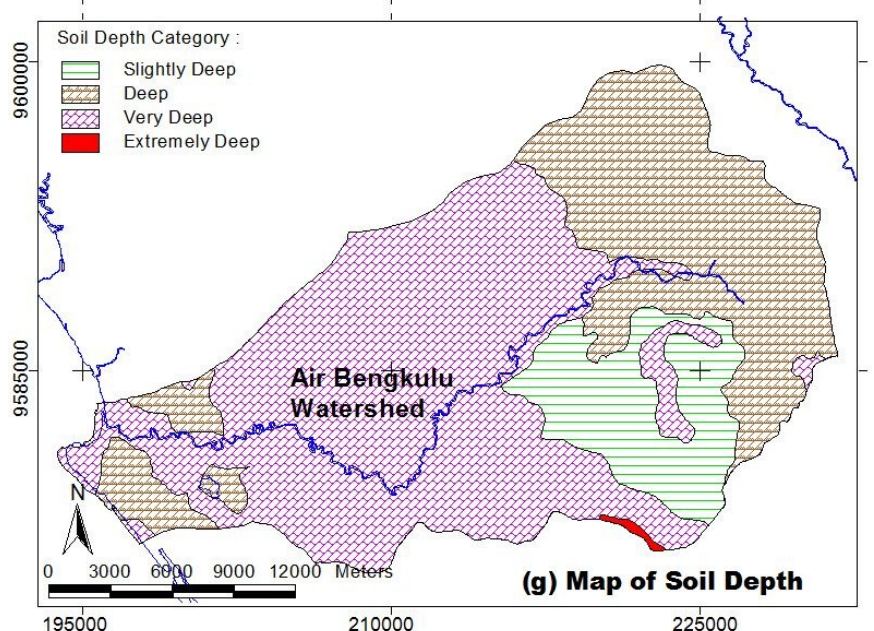

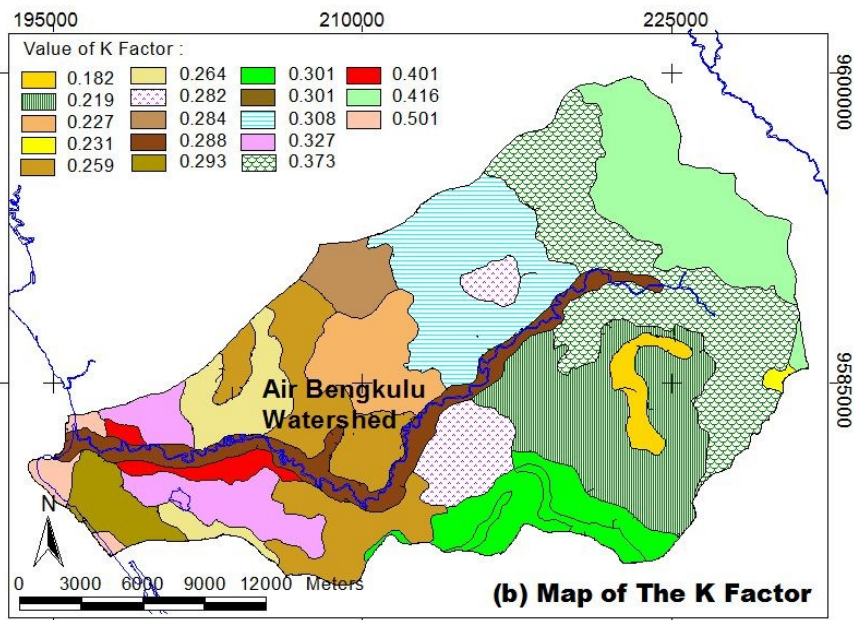
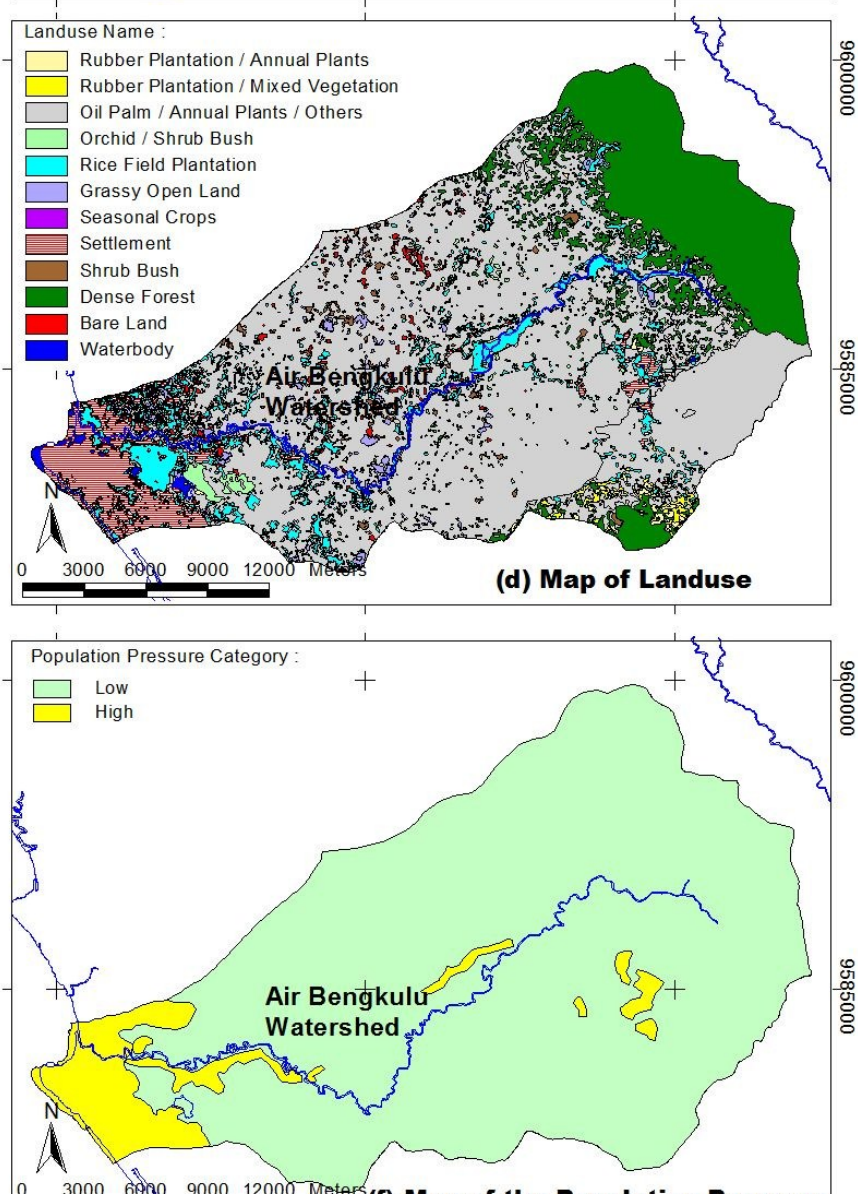

$3000609090001200{ }^{-M e t e r s}(f)$ Map of the Population Pressure

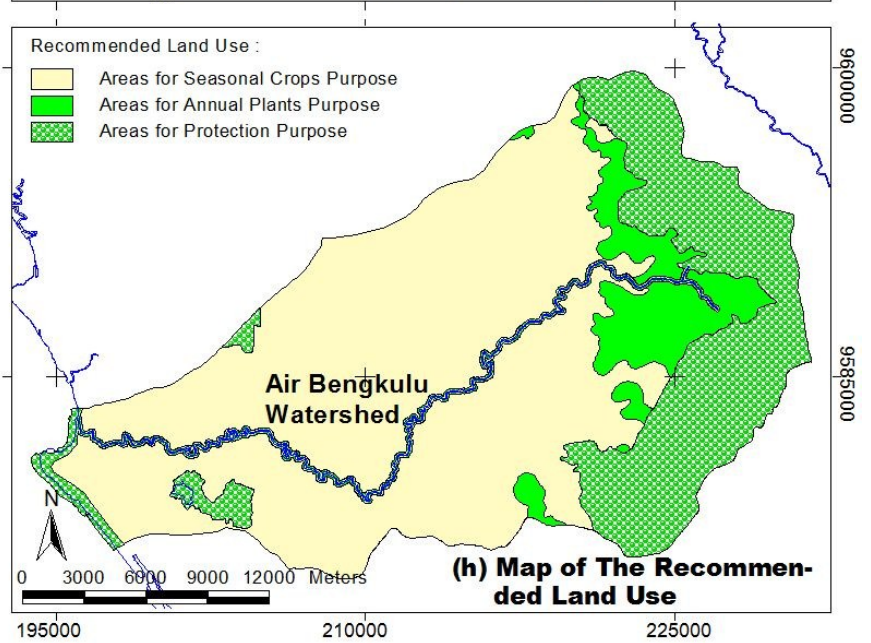

Figure 3. Various Maps as input for the CAP Analysis 
Soil erodibility as presented in Figure 3 (b) shows that smallest value of $\mathrm{K}$ is 0.1818 , while the largest is 0.5015 ). The slope map as presented in Figure 3 (c) showed that the Air Bengkulu Watershed was dominated by a slope of $0-3 \%$ (38.80\%), followed by a slope of $8-15 \%(21.31 \%)$, slope of 15 $-25 \%$ (15.90\%), slope 3-8\% (15.00\%), slope $25-45 \%(8.71 \%)$, and slope $>45 \%(0.28 \%)$. From the slope map, it can be derived LS Factor.

The result of the Landsat 8 OLI image interpretation, as presented in Figure 3 (d), shows that the Air Bengkulu Watershed is dominated by the existence of Rubber Plantation, Palm Plantation and Annual Plants covering an area of 31,605 hectares $(63.15 \%)$ followed by Dense Forests covering 8,805 hectares (17.59\%), while other land uses are below $10 \%$. From the land use data, it can be derived C Factor.

The result of the $\mathrm{P}$ factor as presented in Figure 3 (e) shows that the most widespread factor P-value occurred in agricultural areas at slope $<8 \%$, which amounted to 21,567 hectares $(43.09 \%)$, while the narrowest occurred in agricultural areas at slope $>20 \%$, amounting to 6,247 hectares (12.48\%).

As presented in Figure $3(\mathrm{f})$, the interpretation and delineation results from the Landsat 8 OLI image data shows that the Air Bengkulu watershed is dominated by areas with a Low Population Pressure of $92.5 \%$ of the entire watershed area $(46,298)$, and the rest is a High Population Pressure of $7.5 \%$.

The Soil Depth Map derived from the Land Unit and Soil Map is presented in Figure $3(\mathrm{~g})$. Overall, all areas in the Air Bengkulu Watershed have a depth of $>30 \mathrm{~cm}$.
The result of Map of Recommended Land Use as presented in Figure $3(\mathrm{~h})$, shows that the Air Bengkulu Watershed area is mostly dominated by the Seasonal Crops area of 32,001 hectares, followed by the Protected area of 13,685 hectares, and the Annual Plants area of 4,364 hectares. The protected area is mainly located in the northern coastal area of the Air Bengkulu Watershed.

\section{The results of Erosion Hazard and CAP}

By overlaying analysis among maps of land use, soil type, and slope, new land units are obtained. The number of new land units obtained is 9,227 . After the process of eliminating land units with an area of $<25$ hectares, the number of land units has been reduced to 137. Map of the distribution of land units resulting from overlay analysis is presented in Figure 4.

From Figure 4 it can be seen that the elimination of land units often occurs in the downstream area of the Air Bengkulu Watershed. This happens because indeed in the downstream area is an area where the slope is relatively flat so it is dominated by settlements. The land use is very diverse and small in size which is $<25$ hectares. This is different from the land use in the upstream area which covers $\geq 25$ hectares so that the number of land units is relatively not eliminated. In the upstream area, the land unit which is the location of degraded land (open land, mining area, settlement), has been eliminated because the area of the land unit is $<25$ hectares, so it is joined to a land unit with a larger area.

Each new land unit resulting from the overlaying of the three maps, both the results obtained before and after the elimination of land units, are then can be determined its

Figure 4. Map of Land Unit of the Air Bengkulu Watershed

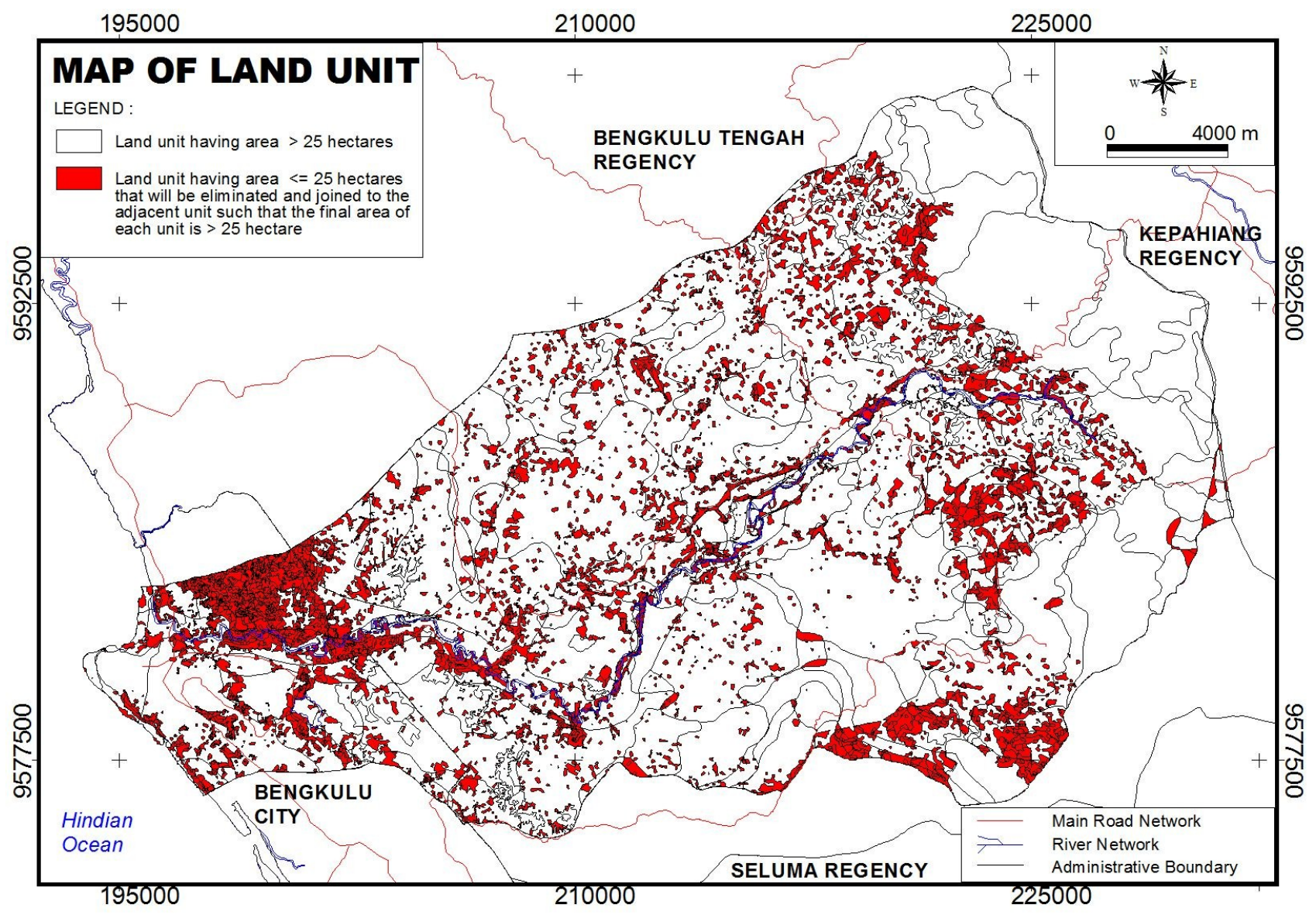


Table 5. The Level of Erosion Hazard at Air Bengkulu Watershed

\begin{tabular}{rlrrrr}
\hline \multirow{2}{*}{ Code } & \multirow{2}{*}{ Level of Erosion Hazard } & Before LUE & \multicolumn{3}{c}{ After LUE } \\
\cline { 3 - 6 } & & Hectare & $\%$ & \multicolumn{3}{c}{ Hectare } & $\%$ \\
\hline 1 & Very Slightly Eroded & 35,548 & 71.03 & 39,021 & 77.96 \\
2 & Slightly Eroded & 9,616 & 19.21 & 9,702 & 19.39 \\
3 & Moderately Eroded & 2,045 & 4.09 & 523 & 1.04 \\
4 & Heavily Eroded & 1,505 & 3.01 & 730 & 1.46 \\
5 & Very Heavily Eroded & 1,336 & 2.67 & 73 & 0.15 \\
& Total & 50,050 & 100.00 & 50,050 & 100.00 \\
\hline
\end{tabular}

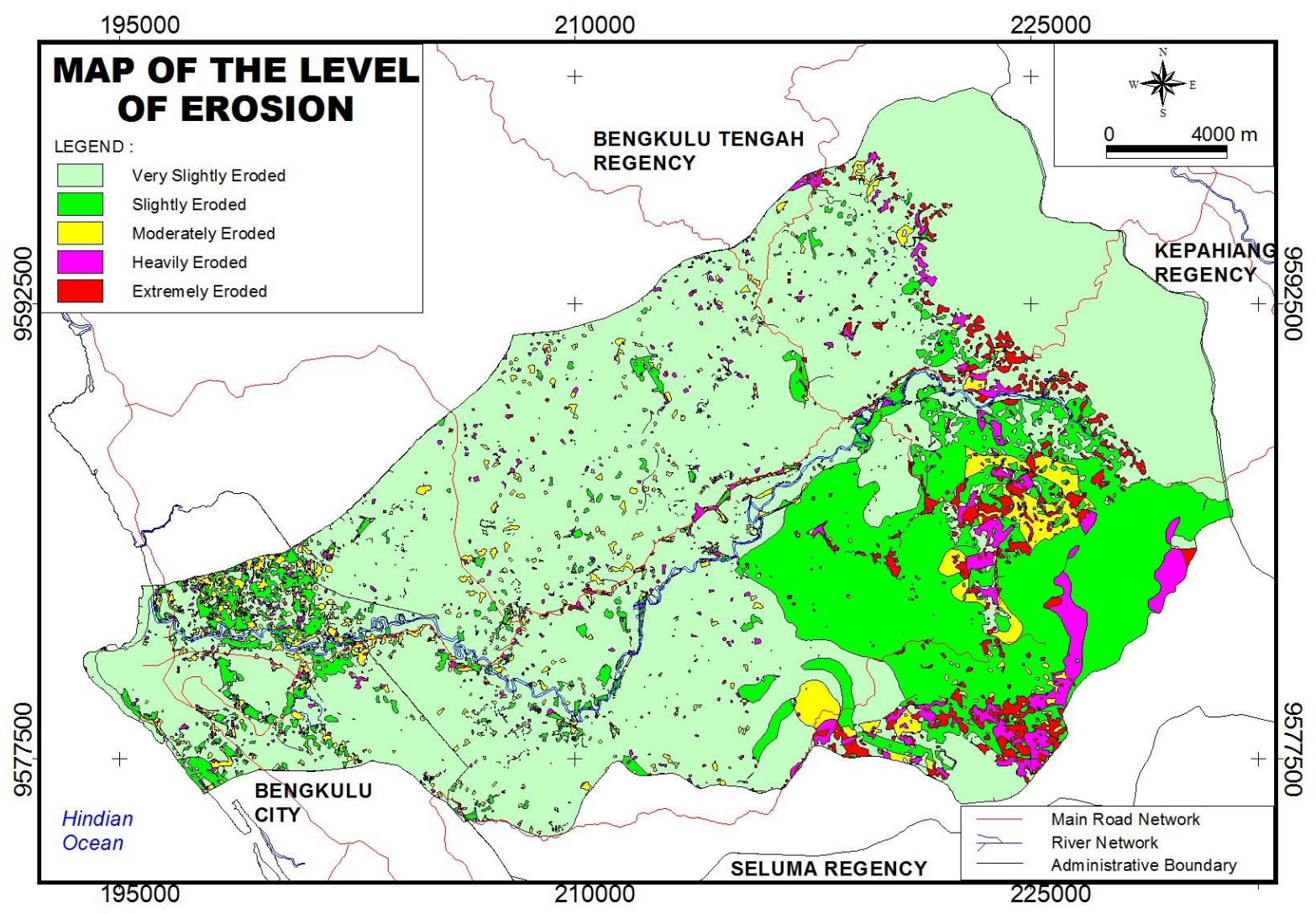

Figure 5. Map of EHL of the Air Bengkulu Watershed

length of the slope (L) and then combined with the S Factor to obtain the LS Factor using the equation (4) and equation (5). Then, an overlay analysis is performed between the new land unit map and the erosivity map ( $\mathrm{R}$ Factor) so that the amount of surface erosion (A) can be determined. Furthermore, EHL can be determined by conducting an overlay analysis between the Erosion Map and the Soil Depth Map, and by applying the criteria as presented in Table 3. The summary of the EHL results is presented in Table 5, while the EHL Map is presented in Figure 5.

Table 5 shows that there was a change in all EHL counts as a result of the elimination of land units. An increase in the area of EHL in the category of Very Slightly Eroded and Slightly Eroded as a result of the elimination process, from 35,548 hectares to 39,021 hectares (in the Very Slightly Eroded category) and from 9,616 hectares to 9,702 hectares (in the Slightly Eroded category).
The elimination process causes the L (Slope Length) of each unit to be longer when compared to the Slope Length before elimination. Thus, logically, the magnitude of erosion will also increase, because erosion is directly proportional to the length of the slope. However, the increase in the Slope Length can be said to be not too significantly for the amount of erosion because the Slope Length must first be converted to the L Factor to calculate erosion.

The increase in EHL area in both categories is thought to have been caused mainly by a decrease in the value of $\mathrm{C}$ Factor as a result of the elimination process. Land use that has a high $\mathrm{C}$ Factor value (for example Settlements with a C Factor $=1$, and Open Land with a C Factor $=0.95$ ) generally has an area of $<25$ hectares. In the elimination process, the Settlement area and the Open Land area are merged into units that have a lower C Factor value (for example, Shrubs or Rice Fields with a C Factor value of 0.010 or Seasonal 
Table 6. The Recommended Engineering Conservation Plan at Air Bengkulu Watershed as a result of land unit elimination process

\begin{tabular}{lrrrr}
\hline \multirow{2}{*}{ Engineering Conservation $^{*}$} & \multicolumn{2}{c}{ Before LUE } & \multicolumn{2}{c}{ After LUE } \\
\cline { 2 - 5 } & Hectare & $\%$ & Hectare & $\%$ \\
\hline T14 & 92 & 0.18 & 12 & 0.02 \\
T1, T2, T4, T6, T7 & 7 & 0.01 & 0 & 0 \\
T1, T2, T4, T6, T7, T8 & 1,707 & 3.29 & 736 & 1.42 \\
T1, T2, T6, T7, T8, T9 & 605 & 1.17 & 55 & 0.11 \\
T1, T2, T3, T6, T7, T8, T9 & 1,392 & 2.68 & 21 & 0.04 \\
T1, T2, T3, T4, T6, T7, T8, T9 & 1,241 & 2.39 & 541 & 1.04 \\
T1, T2, T3, T5, T6, T7, T8, T9 & - & 0.00 & 5 & 0.01 \\
\multicolumn{1}{r}{ Total } & 5,044 & 9.72 & 1,370 & 2.64 \\
\hline
\end{tabular}

${ }^{*}$ Symbol of Engineering Conservation is presented in Table 4

Table 7. The Recommended Vegetatively Conservation Plan at Air Bengkulu Watershed as a result of land unit elimination process

\begin{tabular}{lrrrr}
\hline \multirow{2}{*}{ Vegetative Conservation $^{*}$} & \multicolumn{2}{c}{ Before LUE } & \multicolumn{2}{c}{ After LUE } \\
\cline { 2 - 5 } & Hectare & $\%$ & Hectare & $\%$ \\
\hline V5 & 92 & 0.18 & 12 & 0.02 \\
V4, V11, V14 & 591 & 1.14 & 230 & 0.44 \\
V2, V3, V4, V5, V6, V7 & 1,997 & 3.85 & 72 & 0.14 \\
V4, V9, V10, V12 & 146 & 0.28 & 146 & 0.28 \\
V1, V2, V4, V9, V10, V14 & 62 & 0.12 & - & 0.00 \\
V2, V3, V4, V5, V6, V7, V12 & 44 & 0.08 & 60 & 0.12 \\
V4, V9, V10, V11, V12 & 907 & 1.75 & 361 & 0.69 \\
V4, V9, V10, V11, V12, V14 & 7 & 0.01 & - & 0.00 \\
V2, V3, V4, V5, V6, V7, V9, V10, V12 & 1,197 & 2.31 & 489 & 0.94 \\
\multicolumn{1}{r}{ Total } & 5,044 & 9.72 & 1369.6 & 2.64 \\
\hline
\end{tabular}

${ }^{*}$ Symbol of Vegetatively Conservation is presented in Table 3

Crops with a C Factor value of 0.640 ). For the entire Air Bengkulu Watershed, the average value of the $\mathrm{C}$ Factor before the elimination process is 0.3706 , while the average value of C Factor after the elimination process is 0.3512 .

After overly analysis between EHL Map produced before the process of elimination with the EHL Map produced after the elimination process, it is known that changes have occurred (globally) in the category of 5,972 hectares (11.9\%), while the rest have not changed, which is 44,078 hectares (88.18\%).

After obtaining EHL, then the CAP can be analyzed using the criteria in Table 4, namely by overlying an EHL Map with Population Pressure Maps, Soil Depth Maps, and Recommended Land Use Maps. The analysis was carried out both on the land unit before and after the elimination process. The analysis results are presented in Table 6 (for the results of the Recommended Engineering Conservation
Plan) and Table 7 (for the results of the Recommended Vegetatively Conservation Plan), while the distribution is presented in Figure 6.

Table 6 shows that, for example, before LUE there is an area of 92 hectare recommended for engineering conservation plan as T14 (that is by controling of erosion and runoff from settlement areas including use of soak pits, absorption well, drop structures drains). But, after LUE the area reduced to only 12 hectare. Table 7 shows that, for example, before LUE there is an area of 92 hectare recommended for vegetatively conservation plan as V5 (that is by Grass strip/barrier). But, after LUE the area reduced to only 12 hectare. In general, Table 6 and Table 7 show that the elimination of land units influences the recommended of the Conservation Activity Plan, both conservation that is engineering Recommended and conservation that is recommended vegetatively. For recommended engineering 


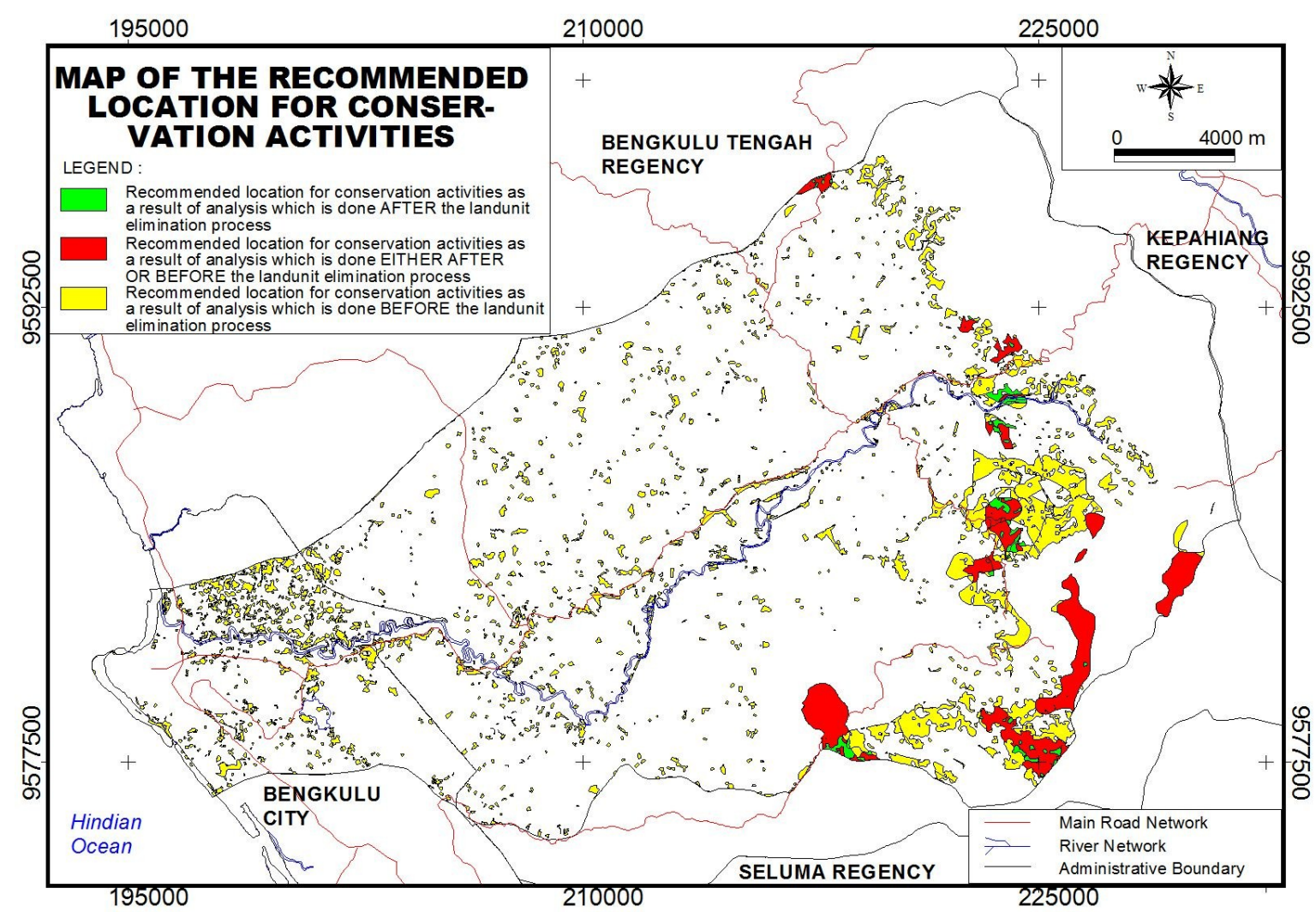

Figure 6. Map of the Recommended for Conservation Activity Plan

conservation, the change reached 4,047 hectares or $77.64 \%$ of the total area, while only 1,165 hectares or $22.36 \%$ did not change. Meanwhile, for the recommended of vegetatively conservation, the change reached 4,030 hectares or $77.6 \%$ of the total area, while only 1,162 hectares or $22.4 \%$ were unchanged.

The elimination of land units influences the recommended of the Conservation Activity Plan, both conservation that is engineering recommended and vegetatively recommended. For recommended engineering conservation, the change reached 4,047 hectares or $77.64 \%$ of the total area, while only 1,165 hectares or $22.36 \%$ did not change. Meanwhile for the recommended of vegetatively conservation, the change reached 4,030 hectares or $77.6 \%$ of the total area, while only 1,162 hectares or $22.4 \%$ were unchanged.

Sulistyo $(2008,2015)$ stated that the process of eliminating land units is only needed if the analysis is done manually where an analysis of map overlays is only possible using maps drawn on transparent (tracing) paper. However, if the analysis is done digitally, using GIS technology, elimination of land units should not be necessary, because no matter how small the area of land units formed as a result of overlay analysis will still be able to calculate erosion, EHL and CAP so that the results will better reflect the erosion at the real conditions in the field. By eliminating land units, there will be deviations from the results. This will result in mistakes in CAP.

Another reason is the possibility of weaknesses in the determination of erosion as suggested by Sulistyo, Gunawan, Hartono, \& Danoedoro (2009) that is the use of vector-based data that has a lot of uncertainty because the data is the result of simplification of natural phenomena. With this simplification, earth information is no longer original as mentioned by DeMers (2008) and Hadmoko (2007). Sulistyo, Gunawan, Hartono, \& Danoedoro (2009) concluded that the calculation of erosion would be more accurate and the uncertainty would be less if the analysis used data that was fully raster-based. Many other researchers also applied raster-based data to determine erosion, for example Benzer (2010), Samanta, Koloa, Pal, \& Palsamanta (2016), Gelagay \& Minale (2016), and Desalegn, Gessesse, \& Tesfay (2018).

\section{Conclusion}

The elimination of land units influences the recommended of the Conservation Activity Plan, both conservation that is engineering recommended and vegetatively recommended. For recommended engineering conservation, the change reached 4,047 hectares or $77.64 \%$ of the total area, while only 1,165 hectares or $22.36 \%$ did not change. Meanwhile for the recommended of vegetatively conservation, the change reached 4,030 hectares or $77.6 \%$ of the total area, while only 1,162 hectares or $22.4 \%$ were unchanged.

\section{Acknowledgement}

Researchers would like to thank profusely to the Chairperson of the Research and Community Service Institute of Bengkulu University and all staff who have helped administration and finance so that this research can be carried out properly. 


\section{References}

Abdurachman, A., Barus, A. \& Kurnia, U. (1985). Pengelolaan Tanah dan Tanaman Untuk Usaha Konservasi Tanah. Bogor: Pusat Penelitian Tanah.

Alkharabsheh, M. M., Alexandridis, T. K., Bilas, G., Misopolinos, N. \& Silleos, N. (2013). Impact of land cover change on soil erosion hazard in northern Jordan using remote sensing and GIS. Procedia Environmental Sciences, 19, 912-921.

Barbero-Sierra, C., Marques, M. J., Ruiz-Pérez, M., Escadafal, R. \& Exbrayat, W. (2015). How is desertification research addressed in Spain? Land versus soil approaches. Land Degradation Development, 26, 423-432.

Benzer, N. (2010) Using the geographical information system and remote sensing techniques for soil erosion assessment. Polish Journal of Environment Study, 19, 881-886.

Bohre, P. \& Chaubey, O. P. (2014). Restoration of degraded lands through plantation forests. Global Journal of Science Frontier Research, 14, 18-27.

Bols, P.L. (1978). The Iso-erodent Maps of Java and Madura: Report of Belgian Technical Assistance Project ATA 105. Bogor: Soil Research Institute.

BPS Kabupaten Bengkulu Tengah (2018), Kabupaten Bengkulu Tengah Dalam Angka

BPS Kota Bengkulu (2018), Kota Bengkulu Dalam Angka

DeMers, M. N. (2008). Fundamental of Geographic Information Systems. New York: John Wiley \& Sons.

Desalegn, A., Gessesse, A. T. \& Tesfay, F. (2018). Developing GISbased soil erosion map using RUSLE of Andit Tid Watershed, Central Highlands of Ethiopia. Journal of Scientific Research \& Reports, 19, 1-13.

Fulazzaky, M. A. \& Gany, A. H. A. (2009). Challenges of soil erosion and sludge management for sustainable development in Indonesia. Journal Environment Management, 90, 2387-2392.

Gelagay, H. S., \& Minale, A. S. (2016). Soil loss estimation using GIS and Remote sensing techniques: A case of Koga watershed, Northwestern Ethiopia. International Soil and Water Conservation Research, 4, 126-136.

Gibbs, H. K. \& Salmon, J. M. (2015). Mapping the world's degraded lands. Journal of Applied Geography, 57, 12-21.

Goldman, S. J., Jackson, K., \& Bursztynsky, T. A. (1986). Erosion and sediment control handbook, New York: McGraw-Hill.

Hadmoko, D. S. (2007). Toward GIS-based integrated landslide hazard assessment: a critical overview. Indonesian Journal of Geography, 39, 55-77.
Ministry of Forestry. (2009). Peraturan Menteri Kehutanan RI Nomor : P. 32/Menhut-II/2009 tentang Tata Cara Penyusunan Rencana Teknik Rehabilitasi Hutan dan Lahan DAS. Jakarta, Ministry of Forestry.

Nawir, A. A., Murniati, \& Rumboko, L. (2008), Rehabilitasi Hutan di Indonesia : Akan Kemanakah Arahnya Setelah Lebih Dari Tiga Dasawarsa ? Bogor: CIFOR.

Prasetya \& Gunawan, T. (2012). Pemanfaatan citra penginderaan jauh dan sistem informasi geografis untuk pemetaan lahan kritis di daerah kokap dan pengasih Kabupaten Kulonprogo. Jurnal Bumi Indonesia, 1, 281-290.

Samanta, S., Koloa, C., Pal, D. K., \& Palsamanta, B. (2016). Estimation of potential soil erosion rate using RUSLE and $\mathrm{E}_{30}$ model. Earth System Environment, 2, 149-162.

Schwab, G. O., Fangmeier, D. D., Elliot, W. J.et al. (1993). "Soil and Water Conservation Engineering," 4th Edition, New York: John Wiley \& Sons.

Sulistyo, B. (2008). Pengaruh Generalisasi Unit Lahan pada Besarnya Erosi. Jurnal Ilmu Kehutanan, 2, 1-11.

Sulistyo, B. (2015). Kajian perubahan tingkat kekritisan lahan sebagai akibat proses eliminasi unit lahan: studi kasus di kawasan pertambangan Danau Mas Hitam, Provinsi Bengkulu. Paper presented at national seminar on Biodiversity. Surakarta: UNS.

Sulistyo, B., Gunawan, T., Hartono, \& Danoedoro, P. (2009). Toward a fully and absolutely raster-based erosion modeling by using RS and GIS. Indonesian Journal of Geography, 41, 149-170.

Supriyono, Iskarni, P. \& Barlian, E. (2015). Kajian dampak penambangan batubara terhadap kualitas air sungai di Sub DAS Hilir Sungai Bengkulu. Jurnal Geografi, 4, 185-197.

Tagore, G.S., Bairagi, G.D., Sharma, N. K., Sharma, R., Bhelawe, S. \& Verma, P. K. (2012). Mapping of degraded lands using remote sensing and GIS techniques. Journal of Agricultural Physics, 12, 29-36.

Tarigan, S. D. (2012). Methods for delineating degraded land at Citarum Watershed, West Java, Indonesia. Journal of Tropical Soils, 17, 267-274.

Wischmeier, W. H. \& Smith, D. D. (1978). Predicting Rainfall Erosion Losses : A Guide to Conservation Planning. Washington DC: USDA Agriculture Handbook. 